\title{
Biosynthesis of D-Alanyl-D-Alanine from L-Alanine by Extracts of a Stabilized L-Form from Streptococcus pyogenes
}

\author{
By P. N. PANDHI AND C. PANOS \\ Department of Biochemistry, Albert Einstein Medical Centre, \\ Northern Division, Philadelphia, Pennsylvania, I9I4I, U.S.A.
}

(Accepted for publication 25 February 1972)

\begin{abstract}
SUMMARY
A stabilized L-form from Streptococcus pyogenes possessed alanine racemase and D-alanyl-D-alanine synthetase, and formed D-alanyl-D-alanine from L-alanine. Comparative rates of synthesis of this dipeptide by coccal and L-form cell-free preparations suggested that this pathway remained unaffected in the L-form, even after prolonged inhibition of wall formation. The terminal nucleotide precursor for wall biosynthesis (UDP-muramic acid-peptide) accumulated in this L-form organism; it probably contained D-alanyl-D-alanine. Lack of D-alanine in glycerol teichoic acid from the L-form only was not caused by a loss of alanine racemase activity.
\end{abstract}

\section{INTRODUCTION}

A stabilized (i.e. non-reverting) L-form from Streptococcus pyogenes is completely devoid of a rigid wall comparable to that of the bacterial form from which it was derived (Panos, 1967), but the initial phase of bacterial wall formation (the biosynthesis of uridine nucleotide precursors) continues to function in this osmotically fragile L-form (Edwards \& Panos, I962). One of the nucleotides accumulating in this organism contained a peptide composed of glutamic acid, lysine and excess alanine and was similar to the UDP (uridine diphosphate)muramic acid-peptide isolated by Park (1952) from Staphylococcus aureus treated with penicillin. Although the isomeric configuration of alanine in this accumulated precursor from the derived L-form was not determined, studies by others showed that in certain bacteria the peptide portion of this nucleotide is a pentapeptide which contains D- and L-alanine (Strominger, 1968). A dipeptide of $\mathrm{D}$-alanine comprises the end portion of this pentapeptide and is formed prior to its insertion into this nucleotide used for mucopeptide formation (Ito \& Strominger, 1962; Neuhaus, 1962).

Alanine is missing in glycerol teichoic acid from this L-form although present in this polymer from the parent organism, Streptococcus pyogenes (Slabyj \& Panos, I97 I).

Changes may have occurred in this stabilized L-form preventing the use of alanine in reactions leading to wall synthesis after permanent loss of the rigid wall. An inability to isomerize the natural isomer of alanine, for example, could explain the accumulation of UDPmuramic acid-peptide and the lack of D-alanine in its glycerol teichoic acid. Consequently we have determined the ability of preparations from a stabilized L-form, and its parent, to isomerize $\mathrm{L}$-alanine and to synthesize D-alanyl-D-alanine. The results are reported here.

\section{METHODS}

Organisms and growth conditions. Streptococcus pyogenes (type 12) and its stabilized L-form were grown and harvested at their mid-logarithmic phases of growth (Panos \& 
Barkulis, I959) and washed as described by Doolin \& Panos (1969). The only difference was that penicillin was omitted from the medium during growth of the L-form.

Bacterial extracts. Washed bacteria ( $0.5 \mathrm{~g}$ wet $\mathrm{wt}$ ) were suspended in I $\mathrm{ml}$ of $\mathrm{O} . \mathrm{I} \mathrm{M}$-tris- $\mathrm{HCl}$, $\mathrm{pH} 7 \cdot 8$, buffer containing $2.5 \mathrm{mM}$-glutathione and from 15 to $30 \mathrm{ml}$ of this suspension disrupted in a French pressure cell (Milner, Lawrence \& French, 1950). Unbroken bacteria and debris were removed by centrifugation at $39000 \mathrm{~g}$ for $\mathrm{Io} \mathrm{min}$. The supernatant extract was used as the enzyme source for these studies and was stable for at least 4 months at $-15^{\circ} \mathrm{C}$.

Assays and synthesis of labelled D-alanyl-D-alanine. D-alanyl-D-alanine synthetase was assayed as described by Ito, Nathenson, Dietzler, Anderson \& Strominger (I966). For the combined assay of alanine racemase and D-alanyl-D-alanine synthetase, uniformly labelled $\left[{ }^{14} \mathrm{C}\right] \mathrm{L}$-alanine $(0.5 \mathrm{mCi} / \mathrm{mmol})$ replaced $\left[\mathrm{U}-{ }^{14} \mathrm{C}\right] \mathrm{D}$-alanine. Radioactive $\mathrm{D}$-alanyl-D-alanine was prepared using the same conditions as for the assay except that carrier free $\left[\mathrm{U}-{ }^{14} \mathrm{C}\right] \mathrm{D}$ alanine was used and reaction mixtures were scaled-up tenfold. A typical reaction mixture contained $50 \mu \mathrm{l}$ of $0.5 \mathrm{M}$-tris- $\mathrm{HCl}$ buffer, $\mathrm{pH} 7.8 ; 80 \mu \mathrm{l}$ of $0.05 \mathrm{M}-\mathrm{MnCl}_{2} ; 50 \mu \mathrm{l}$ of $\mathrm{I} \cdot 0 \mathrm{M}-\mathrm{KCl}$; $20 \mu \mathrm{l}$ of $0 . \mathrm{I} \mathrm{M}-\mathrm{ATP} ; 5 \mu \mathrm{Ci}(0 . \mathrm{I} 3 \mu \mathrm{mol})$ of [U- $\left.{ }^{14} \mathrm{C}\right] \mathrm{D}$-alanine and $200 \mu \mathrm{l}(2.4 \mathrm{mg}$ protein) of extract of Streptococcus pyogenes in a final volume of $500 \mu$ l. Reaction mixtures were incubated for $\mathrm{I} 50 \mathrm{~min}$ at $37^{\circ} \mathrm{C}$ and the reaction terminated by placing all test-tubes in a boiling water bath for $3 \mathrm{~min}$. The precipitate obtained was removed by centrifugation and the radioactive supernatant chromatographed as described by Ikawa \& Snell (I958). Biorad AG-50W $\times 8\left(\mathrm{H}^{+}\right.$form $), 200$ to 400 mesh, was suspended in deionized water and poured into a $\mathrm{I} \cdot 5 \mathrm{~cm}$ column to $57 \mathrm{~cm}$. The radioactive supernatant was quantitatively transferred to the column and eluted successively with deionized water (I $20 \mathrm{ml}$ ), $0.5 \mathrm{~N}-\mathrm{HCl}$ (I $20 \mathrm{ml}$ ) and I.0 N-HCl (approx. $500 \mathrm{ml}$ ). Fractions $(5 \mathrm{ml})$ were collected and $0.1 \mathrm{ml}$ portions counted from only those eluted with $\mathrm{r} \cdot \mathrm{O} \mathrm{N}-\mathrm{HCl}$.

Optical configuration. The optical configuration of the alanine in this dipeptide was determined after acid hydrolysis and conversion of alanine to pyruvate by $\mathrm{D}$-amino acid oxidase (Lynch \& Neuhaus, 1966).

Paper chromatography. All paper chromatography was descending, with Whatman no. I paper. Solvent (A) contained $n$-butanol+glacial acetic acid + water $(4: 1: 1, v / v)$; solvent (B), isobutyric acid + concentrated ammonium hydroxide + water $(66: 1: 33, v / v)$; solvent (C), pyridine + water $(4: \mathrm{I}, \mathrm{v} / \mathrm{v})$. Amino acids were detected with ninhydrin.

Measurement of activity. Aqueous samples $(0.1 \mathrm{ml})$ were counted in Bray's scintillation fluid (Io ml) (Bray, 1960). Radioactive spots were cut from chromatograms and deposited into a toluene scintillation fluid ( $\mathrm{IO} \mathrm{ml}$ ) of the following composition: Io $\mathrm{g}$ of 2,5-diphenyloxazole (PPO), $0.5 \mathrm{~g}$ of $\mathrm{I}, 4$-bis-[2-(5-phenyloxazolyl)]-benzene (POPOP), I 1 toluene, before counting. All samples were counted in a Packard Tri-Carb scintillation counter.

Autoradiography. Standard Kodak No-Screen X-ray film was used throughout and exposed at room temperature for from 2 to Io days depending upon the level of radioactivity expected.

Protein determination. Protein was determined by the method of Lowry, Rosebrough, Farr \& Randall (I95I) with bovine serum albumin as the standard.

Chemicals. Uniformly labelled $\left[{ }^{14} \mathrm{C}\right] \mathrm{L}$-alanine $(137 \mathrm{mCi} / \mathrm{mmol})$ and $\mathrm{D}$-alanine $(40 \mathrm{mCi} / \mathrm{mmol})$ were purchased from New England Nuclear Co., Boston, Massachusetts, U.S.A. and Amersham/Searle Co., Arlington Heights, Illinois, U.S.A., respectively. Non-radioactive D-alanyl-D-alanine was obtained from Cyclo Chemical Co., Los Angeles, California, U.S.A. and L-alanyl-L-alanyl-L-alanine from Cyclo Chemical Co. and Sigma Chemical Co., St Louis, Missouri, U.S.A. D-Cycloserine, D-amino acid oxidase and glutamic-pyruvic transaminase were purchased from Sigma Chemical Co. 


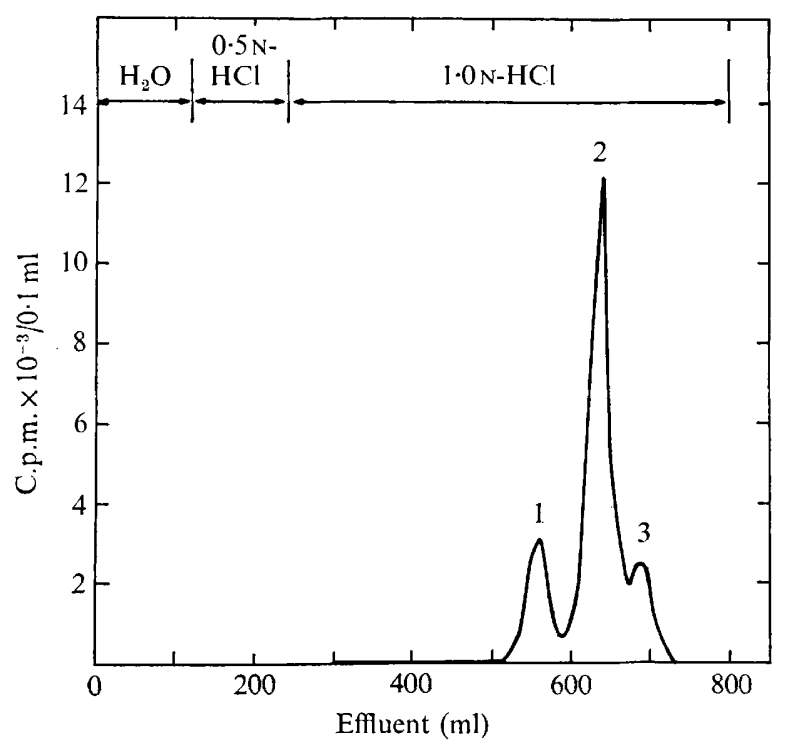

Fig. I. Ion exchange chromatogram of a reaction mixture with an extract from the streptococcus incubated with $\left[\mathrm{U}-{ }^{14} \mathrm{C}\right] \mathrm{D}$-alanine. Peak $\mathrm{I}$, alanyl-alanine; peak 2, alanine; peak 3, contaminant or artifact (see text).

Table I. Paper chromatographic mobility of enzymatically synthesized $\mathrm{D}$-alanyl-D-alanine by streptococcal and $L$-form extracts

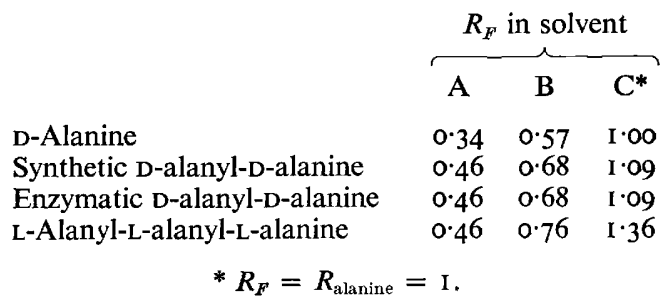

RESULTS

Synthesis of D-alanyl-D-alanine from D-alanine by extracts of Streptococcus pyogenes and its stabilized L-form. Uniformly labelled $\left[{ }^{14} \mathrm{C}\right] \mathrm{D}$-alanyl-D-alanine was prepared using the assay method for D-alanyl-D-alanine synthetase (see Methods). A typical elution profile obtained with a streptococcus extract is shown in Fig. I. Peaks I and 2 were an alanine dipeptide and alanine, respectively, according to co-chromatography with unlabelled $\mathrm{D}$-alanyl-D-alanine and D-alanine by both paper chromatography and by autoradiography; the $R_{F}$ of D-alanyl-D-alanine from peak I was the same by both techniques. Table I tabulates the $R_{F}$ values obtained for the products in the different solvent systems. The resolution of alanyl-alanine from alanine by column chromatography, though adequate, was not as complete as that obtained by Ikawa \& Snell (1958) and Ito \& Strominger (I962). Hydrolysis of the material from peak I with $6 \mathrm{~N}-\mathrm{HCl}$ at $\mathrm{I} I 0{ }^{\circ} \mathrm{C}$ for $\mathrm{I} 6 \mathrm{~h}$ always yielded only alanine as identified by paper co-chromatography and autoradiography with unlabelled and labelled alanine (Table $\mathrm{r}$ ). The probable origin of peak 3 is discussed below.

Identical column (Fig. I) and paper (Table I) chromatographic results were obtained 


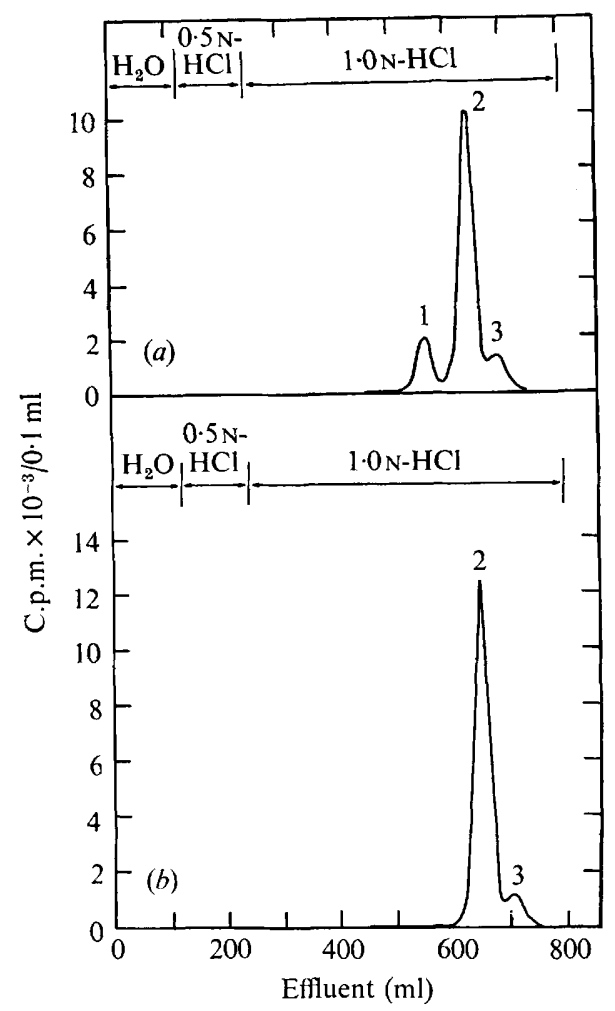

Fig. 2. Ion exchange chromatograms of reaction mixtures with extracts from the L-form incubated with $(a)\left[\mathrm{U}-{ }^{14} \mathrm{C}\right] \mathrm{L}$-alanine and $(b)\left[\mathrm{U}-{ }^{14} \mathrm{C}\right] \mathrm{L}$-alanine plus D-cycloserine. Peak $\mathrm{I}$, alanyl-alanine; peak 2, alanine; peak 3, contaminant or artifact (see text).

Table 2. Determination of optical configuration of alanine residues in alanyl-alanine synthesized from $\left[\mathrm{U}^{14} \mathrm{C}\right] \mathrm{L}$-alanine by an extract from the $L$-form

\begin{tabular}{|c|c|c|c|}
\hline & \multirow[b]{2}{*}{ Untreated } & \multicolumn{2}{|c|}{ Counts per minute after treatment with } \\
\hline & & D-amino acid oxidase & transaminase \\
\hline$\left[\mathrm{U}-{ }^{14} \mathrm{C}\right] \mathrm{D}$-Alanine & 628 & $5670 \mathrm{I}$ & - \\
\hline$\left[\mathrm{U}-{ }^{14} \mathrm{C}\right] \mathrm{L}$-Alanine & 68106 & 209 & $6539 \mathrm{I}$ \\
\hline Dipeptide hydrolysate & 27680 & 27794 & 760 \\
\hline
\end{tabular}

when extracts of the L-form ( $8 \mathrm{mg}$ protein $/ 500 \mu \mathrm{l}$ reaction mixture) replaced those of the parent Streptococcus pyogenes.

Synthesis of D-alanyl-D-alanine from $\mathrm{L}$-alanine by extracts of the L-form. Since the previous experiments indicated that the $\mathrm{L}$-form was capable of alanine dipeptide formation, they were repeated with labelled L-alanine to detect any racemase activity. A typical elution profile (Fig. 2a) illustrates the ability of the L-form to continue to synthesize alanyl-alanine from L-alanine. D-Cycloserine is a potent inhibitor of alanyl-alanine synthetase and alanine racemase (Strominger, Ito \& Threnn, 1960 ). When $\left[{ }^{14} \mathrm{C}\right] \mathrm{L}$-alanine was incubated with extracts of the $\mathrm{L}$-form in the presence of $4 \mathrm{MM}$-D-cycloserine and the reaction mixture resolved by column chromatography, only alanine (peak 2 ) and peak 3 were observed (Fig. $2 b$ ). Clearly synthesis of alanine dipeptide was inhibited by this antibiotic; indicating that the dipeptide formed in the absence of $\mathrm{D}$-cycloserine was probably D-alanyl-D-alanine. 


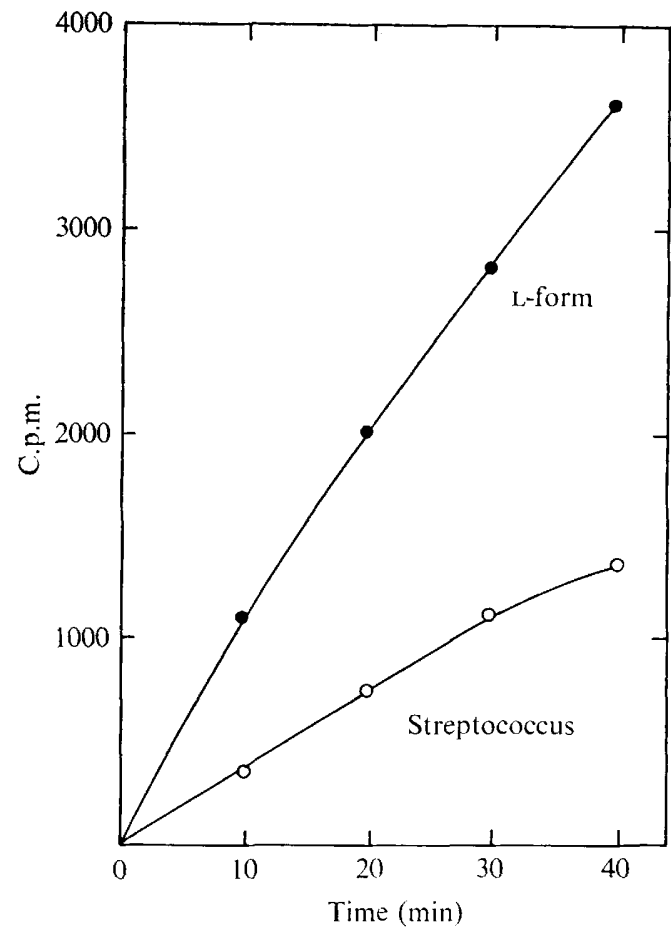

Fig. 3. Combined rate of racemase and D-alanyl-D-alanine synthetase activities in extracts. Specific activity of enzymes $=I \cdot 0$ and $1 \cdot 3 \mathrm{nmol} / \mathrm{min} / \mathrm{mg}$ protein for streptococcal and L-form extracts, respectively. Radioactivity from dipeptide spot from segmented paper chromatograms.

The DNP-derivative of this peptide was prepared as described by Grebner, Hall \& Neufeld (I966) except that DNP-peptide was extracted into ethyl ether instead of ethyl acetate after acidification of the reaction mixture. It was hydrolysed in $6 \mathrm{~N}-\mathrm{HCl}, 105{ }^{\circ} \mathrm{C}$ for $6 \mathrm{~h}$, and DNPalanine and alanine separated and counted (Ikawa \& Snell, I958). Of the original counts in the sample (70 700 c.p.m. in a typical experiment), I6\% (I I 524 c.p.m.) appeared in DNPalanine and $16 \%$ (I 892 c.p.m.) in alanine. This equal distribution of radioactivity in the two halves of this dipeptide confirms the evidence that the dipeptide was D-alanyl-D-alanine. Low recoveries of radioactivity in such experiments have also been obtained by others (Ikawa \& Snell, 1958) and probably reflect incomplete formation of derivatives.

The optical configuration of the alanine residues was confirmed enzymatically. The radioactive dipeptide (peak I, Fig. 2a) was hydrolysed with $6 \mathrm{~N}-\mathrm{HCl}$ as above and the acid removed in vacuo. Portions of this hydrolysate were treated with D-amino acid oxidase and glutamic-pyruvic transaminase and the pyruvate formed, if any, separated as described by Lynch \& Neuhaus (1966) and counted. Adequate controls included use of labelled L- and $\mathrm{D}$-alanine. The quantitative conversion of $\mathrm{D}$-alanine to pyruvate by $\mathrm{D}$-amino acid oxidase, but not by the transaminase, is apparent in Table 2 and indicates that the alanine residues in newly synthesized alanyl-alanine are of the $\mathrm{D}$ configuration.

Combined rate of alanine racemase and alanyl-alanine synthetase in extracts. The combined rate of the racemase and synthetase enzymes in each preparation was assayed as detailed by Ito et al. (I966) with $\left[\mathrm{U}-{ }^{14} \mathrm{C}\right] \mathrm{L}$-alanine as substrate. Fig. 3 illustrates the formation of D-alanyl-D-alanine from labelled L-alanine by these two preparations. The rate of formation remained linear over $40 \mathrm{~min}$ for each preparation and all reactions were terminated after 
$60 \mathrm{~min}$. The specific activity for these two enzymatic reactions in preparations of the parent coccus was $\mathrm{I} \cdot 3 \mathrm{nmol} / \mathrm{min} / \mathrm{mg}$ protein as compared with $\mathrm{I} \cdot 0 \mathrm{nmol} / \mathrm{min} / \mathrm{mg}$ protein in those from the L-form.

Origin of the third peak eluted during column chromatography. The material comprising peak 3 (Fig. I to 3) had the same mobility as alanine in solvent system A. However, it continued to appear in elution profiles of reaction mixtures incubated with $\mathrm{D}$-cycloserine (Fig. 2b). It was detected in labelled D- and L-alanine as received from two different vendors so it was either an impurity present initially or formed by radiolysis (Oldham, 1970).

\section{DISCUSSION}

This L-form has been unable to synthesize a rigid wall for the past 15 years (Panos, 1969). The importance of the $\mathrm{D}$ and $\mathrm{L}$ isomers of alanine and $\mathrm{D}$-alanyl-D-alanine in bacterial wall mucopeptide formation is well known and will not be pursued here. However, the detection of these two reactions still operating in a streptococcal L-form completely devoid of a wall is significant. It demonstrates that the accumulation of the terminal wall precursor (uridine nucleotide-muramic acid-peptide) in this L-form (Edwards \& Panos, I962) is not due to the inability of this organism to isomerize the natural isomer of alanine or to synthesize the dipeptide end of the peptide portion of this precursor. Therefore, these findings, together with our earlier results (Edwards \& Panos, I962), indicate that this nucleotide which accumulated in the L-form is not an alternative nucleotide with an altered peptide side chain. Finally, no significant difference was noted in the rate of synthesis of D-alanyl-D-alanine from L-alanine by coccal or L-form extracts. This suggests that prolonged inhibition of wall formation has not diminished the rate at which this metabolic route can operate.

Plapp \& Kandler (1964) established that the L-phase variants (stable and unstable L-forms) of Proteus mirabilis contain alanine racemase. They also stated that this enzyme '.. is not lost during the penicillin induced transition of the bacterial form of $P$. mirabilis to the Lphase, although the enzyme has no further function in the mucopolymer-free L-phase'. As now shown, however, there is a definite need for this enzyme in this mucopeptide-free streptococcal L-form. It lies in the continued formation of the terminal nucleotide precursor for wall synthesis still found accumulating in this L-form (Edwards \& Panos, 1962). The inhibition of D-alanyl-D-alanine, the dipeptide end of this peptide containing nucleotide, by D-cycloserine (see below) substantiates this belief.

As already indicated, glycerol teichoic acid isolated from this L-form, but not that from its parental Streptococcus pyogenes, is devoid of D-alanine (Slabyj \& Panos, I97I). Yet an actively functioning alanine racemase is present and D-alanyl-D-alanine is formed by the L-form. The inability to insert D-alanine into glycerol teichoic acid in the L-form may be due, instead, to a lack or inhibition of $\mathrm{D}$-alanine:membrane acceptor ligase (Reusch \& Neuhaus, I971).

Alanine racemase seems to be absent from the few mycoplasmas examined thus far (Plapp \& Kandler, I964; Smith, I97I). This has led investigators to suggest that this enzyme may serve as a criterion for differentiating between a mycoplasma and an L-form of a bacterium (Plapp \& Kandler, 1964). However, the finding of this enzyme in this coccus and its stabilized L-form precludes its usefulness for differentiating between stabilized and unstabilized bacterial L-forms.

D-Cycloserine inhibits bacterial wall formation by inhibiting reactions catalysed by alanine racemase and D-alanyl-D-alanine synthetase which leads to formation of this dipeptide; it has been successfully employed in the transformation of a bacterium to an L-form (Ward \& 
Martin, 1962). This antibiotic is without affect upon growth of this streptococcal L-form (Panos, Cohen \& Fagan, I967); it affected growth of '. . . the mucopolymer containing L-phase only' (Plapp \& Kandler, 1964). These results now suggest that, while not affecting growth, D-cycloserine probably causes accumulation of UDP-muramic acid-tripeptide in this streptococcal L-form instead of UDP-muramic acid-pentapeptide (with its dipeptide of D-alanine).

Dr P. N. Pandhi was a postdoctoral fellow in these laboratories. These investigations were supported by a grant (AI-04543) from the National Institute of Allergy and Infectious Diseases, U.S. Public Health Service and a contract (NR I36-756) from the Office of Naval Research. One of us (C. P.) is a Senior Career Development Awardee (U.S.P.H. 5-K 3-GM I 5,53I).

\section{REFERENCES}

BRAY, G. A. (1960). A simple efficient liquid scintillator for counting aqueous solutions in a liquid scintillation counter. Analytical Biochemistry I, 279-285.

Doolin, L. E. \& Panos, C. (1969). The alpha-glucosidases of Streptococcus pyogenes and derived L-form. Biochimica et biophysica acta $184,27 \mathrm{I}-280$.

Edwards, J. \& Panos, C. (1962). Streptococcal L-forms. V. Acid-soluble nucleotides of a group A streptococcus and derived L-form. Journal of Bacteriology 84, I 202-I 208.

GrebNer, E. E., Hall, C. W. \& Neufeld, E. F. (1966). Glycosylation of serine residues by a uridine diphosphate xylose:protein xylosyltransferase from mouse mastocytoma. Archives of Biochemistry and Biophysics 116, 39I-398.

IKAWA, M. \& SNELL, E. E. (1958). The nature of trichloroacetic acid-soluble derivatives of D-alanine in Streptococcus faecalis. Archives of Biochemistry and Biophysics 78, 338-347.

Ito, E., Nathenson, S. G., Dietzler, D. N., Anderson, J. S. \& Strominger, J. L. (I966). Formation of UDP-acetyl muramyl peptides. In Methods in Enzymology, vol. 8. Edited by E. F. Neufeld \& V. Ginsburg. New York: Academic Press.

Ito, E. \& Strominger, J. L. (I962). Enzymatic synthesis of the peptide in bacterial uridine nucleotides. II. Enzymatic synthesis and addition of D-alanyl-D-alanine. Journal of Biological Chemistry 237, 2696-2703.

Lowry, O. H., Rosebrough, N. J., Farr, A. L. \& Randall, R. J. (I95I). Protein measurement with the Folin reagent. Journal of Biological Chemistry 193, 265-275.

LynCH, J. L. \& Neuhaus, F. C. (1966). On the mechanism of action of the antibiotic $O$-carbamyl-D-serine in Streptococcus faecalis. Journal of Bacteriology 9r, 449-460.

Milner, H. W., Lawrence, N. S. \& French, C. S. (1950). Colloidal dispersion of chloroplast material. Science, New York III, 633-634.

Neunaus, F. C. (1962). The enzymatic synthesis of D-alanyl-D-alanine. I. Purification and properties of D-alanyl-D-alanine synthetase. Journal of Biological Chemistry 237, 778-786.

OLdHAM, K. G. (1970). Radiochemical enzyme assays: factors affecting their sensitivity and the selection of optimum conditions for assays. International Journal of Applied Radiation and Isotopes 2I, 42 I-429.

PANos, C. (1967). Biochemistry of bacterialL-form growth and structure. In A Microbial Enigma: Mycoplasma and Bacterial L-forms. Edited by C. Panos. Cleveland: World Publishing Co.

Panos, C. (1969). Chemical and physiological aspects of the bacterial L-phase variant. In The Mycoplasmatales and the L-Phase of Bacteria. Edited by L. Hayflick. New York: Appleton-Century-Crofts.

Panos, C. \& Barkulis, S. S. (1959). Streptococcal L-forms. I. Effect of osmotic change on viability. Journal of Bacteriology 78, 247-252.

Panos, C., Cohen, M. \& Fagan, G. (1967). Antibiotic inhibition and binding studies with a group A streptococcal L-form. Journal of General Microbiology 46, 299-304.

PARK, J. T. (1952). Uridine-5'-pyrophosphate derivates. III. Amino acid containing derivatives. Journal of Biological Chemistry 194, 897-904.

PlapP, R. vON \& KANDLER, O. (1964). Vorkommen und Bedeutung der Alaninracemase bei Proteus mirabilis, dessen L-Phasen und bei Mycoplasma. Zeitschrift für Naturforschung $19 b$, I $135^{-1}$ I 42.

ReUSCH, V. M., JUN. \& Neuhaus, F. C. (I971). D-alanine:membrane acceptor ligase from Lactobacillus casei. Journal of Biological Chemistry 246, 6r 36-6r 43. 
SlabYJ, B. M. \& Panos, C. (197I). Glycerol teichoic acid from Streptococcus pyogenes and stabilized L-form. Bacteriological Proceedings, $15 \mathrm{IG}$.

SmITH, P. F. (197I). Dynamics of reproduction and growth B. Biosynthesis 2. Amino acids and proteins In The Biology of Mycoplasmas. Edited by P. F. Smith. New York: Academic Press.

Strominger, J. L. (1968). Enzymatic reactions in bacterial cell wall synthesis sensitive to penicillins and other antibacterial substances. In Microbial Protoplasts, Spheroplasts and L-Forms. Edited by L. B. Guze. Baltimore: Williams and Wilkins Co.

Strominger, J. L., Ito, E. \& Threnn, R. M. (1960). Competitive inhibition of enzymatic reactions by oxamycin. Journal of the American Chemical Society 82, 998-999.

WARD, J. R. \& Martin, C. H. (1962). Production of L-phase variants of bacteria with cycloserine. Proceedings of the Society for Experimental Biology and Medicine III, 156-160. 